\title{
The Sociocultural
}

\section{Feminist Implications of "Rumpelstiltskin" by the Brothers Grimm}

\section{Emily Barsic, Emma Hartman, \& Alexis Lawhorn, Ball State University}

$\mathbf{F}$ of joy and inspiration for their audiences, but they can also portray the monsters that lurk within a culture. Rumpelstiltskin seems like an unlikely choice for a monster, but, like all literary monsters, he embodies the fears of the time when he was created. While this story was traditionally orally told, we will be using the version by the Brothers Grimm, based on European folklore and published in 1812. This edition is based on the first English translation by Edgar Taylor and Marian Edwardes in 1823. Our edition of "Rumpelstiltskin" will focus on fears relating to women's roles in the early nineteenth century, particularly women's roles in marriage and industry. We will discuss the repercussions and benefits of how "Rumpelstiltskin" has evolved to fit into the modern era in the form of television and children's books.

\section{WOMEN'S RIGHTS AT THE TIME OF "RUMPELSTILTSKIN"}

This tale has served throughout the decades as a tale of caution for women, in which they are told to behave and to conform to their place in society. However, "Rumpelstiltskin" is still shared in the modern era both as a warning and as an 
example of the progression of women's rights. According to the article, "Placing Women in History: Definitions and Challenges" by Gerda Lerner, most women within the early nineteenth century were not even perceived to be involved in the important events of history: "The resulting history of 'notable women' does not tell us much about those activities in which most women engaged, nor does it tell us about the significance of women's activities to society as a whole" (5). Women's activities and accomplishments were overshadowed by men's and deemed irrelevant to history. This was due to the fact that women's roles were restricted to the domestic sphere. In 1838 Sarah Stickney Ellis stated the gendered expectations for women quite plainly in her work, "The Women of England: Their Social Duties and Domestic Habits." In the following quote, Ellis describes how a domesticated nineteenth-century woman influences her husband:

When the snares of the world were around him, and temptations from within and without have bribed over the witness in his own bosom, he has thought of the humble mistress who sat at alone, guarding the fireside comforts of his distant home; and the remembrance of her character, clothed in moral beauty, has scattered the clouds before his mental vision, and sent him back to that beloved home, a wiser and a better man. (1525)

According to Ellis, it is the woman's duty to lead her husband back to moral ground, so that even the mere thought of her-as she sits fireside "clothed in moral beauty"-may encourage him to return to his home, in order to become "a wiser and a better man." The Victorian woman is supposed to "guard the hearth" and not exit the domestic sphere. This ensures that she stays pure in order to purify her husband after he returns from his duties within the public sphere, from the "temptations of greed and pride" (Ellis 1526).

\section{FEMALE MARRIAGE ROLES DURING THE TIME OF "RUMPELSTILTSKIN"}

Many fairy tales from the nineteenth century concluded with a woman being married, and this remains true for the protagonist in "Rumpelstiltskin." However, in the nineteenth century, men and women held quite different views on marriage than they do today. During this time, many in society believed women should not try too hard to attain a husband, as they thought it was improper to express what was viewed as inappropriate sexual appetite. In fact, such people thought marriage was solely a means for a woman to become a mother and not a way to fulfill her desires. However, it must be noted that not all held this view. Mary Wollstonecraft defines marriage in "Vindication of the Rights of Women." She says:

To speak disrespectfully of love is, I know, high treason against 
sentiment and fine feelings; but I wish to speak the simple language of truth, and rather to address the head than the heart. To endeavour to reason love out of the world, would be to out Quixote Cervantes, and equally offend against common sense; but an endeavour to restrain this tumultuous passion, and to prove that it should not be allowed to dethrone superior powers, or to usurp the sceptre which the understanding should very coolly wield, appears less wild. (299)

Clearly, not all thought that love was an unnecessary part of the marriage contract.

Sex, however, was another matter. One who held that women did not experience sexual feeling was the doctor, William Acton. He states, “The majority of women (happily for them) are not very much troubled with sexual feeling of any kind" (Hume 177). Acton and those he influenced did not even believe that women had a sexual drive to begin with. However, not all those considering female sexuality at the time were convinced that women did not have a sexual appetite. Elizabeth Blackwell, the first licensed female doctor in Britain, said,

Those who deny sexual feeling to women, or consider it so light a thing as hardly to be taken into account in social arrangements, confound appetite and passion; they quite lose sight of this immense spiritual force of attraction, which is distinctly human sexual power, and which exists in so very large a proportion in the womanly nature. (Hume 179) Blackwell is saying here that women in fact experience sexual feeling, but it is not so much a mere appetite; it is in fact tied to passion and attraction.

Auguste Debay, who published a marriage manual which was best-selling in France during the nineteenth century, admitted that women have sexual desire (Hume 176). However, he felt that a woman should regulate her husband's overzealous appetite, while allowing him to "exercise his rights two to four times a week" at the age of twenty to thirty years, with other intervals suggested at different ages (Debay qtd. in Hume 177).

During this time, women were also not allowed to talk to men unless a married female escort was present (Hume 177). The Grimms' story "Rumpelstiltskin" exemplifies a woman stepping outside the bounds of acceptability when she commits the taboo act of speaking to Rumpelstiltskin, a male stranger, on her own. The story also reflects the way a woman's sexuality is repressed when the miller and the king strike a deal and exchange the daughter as if she is a piece of property, which she quite literally is. Whether the girl would prefer to marry the king, and later conceive a child, is never taken into consideration by the men in "Rumpelstiltskin."

Before the Married Property Act was passed in 1882 in Britain, a woman's wealth was transferred to her husband. This meant that wives were commodified 
and value was placed on them based on their personal wealth and possessions. In addition, women were to be under the care of a man at all times, and this duty transferred from father to husband at the point of marriage. A father had to give permission for a man to marry his daughter, and this choice often depended upon whether he thought the man could financially support his daughter. If women were to have a job after they were married, all of their earnings would belong to their husbands, but the husbands were expected to be the sole provider in the household.

In "Rumpelstiltskin" women are controlled by men; the maid is controlled by the king - her future husband - and Rumpelstiltskin. This feature of control was modeled after events during the time period. Chauncey Savage discussed the Married Women's Act of 1870 and how it impacted individuals in his article, "Some Points of Comparison between English and American Legislation, as to the Married Women's Property":

This act gave a married woman her earnings and the right to trade; allowed her 'to deposit in banks, and to hold and transfer stocks, loans and so forth, as if sole; suffered her to hold to her separate use any property descending to her from an intestate, and money coming to her by deed and will, not exceeding in amount $2001 . ;^{1}$ [sic] and empowered her to sue or be sued alone in matters relating to her separate property. (4)

Essentially, women were separate financial entities from their husbands. This would have allowed major progress for women's rights, if the act had not been repealed.

Similar notions are represented within "Rumpelstiltskin," as the maid is forced to create large sums of gold for the king, while she retains no autonomy or financial separation. Savage states that, in reference to England's legislation:

A clause in the Matrimonial and Divorce Causes Act of 1857, gave to a woman deserted by or judicially separated from her husband, power to act as a feme sole, obtaining in the former case from a court or magistrate a so-called protection order against her husband's creditors. A curious statute in 1878 allowed the same privilege in cases of aggravated assault upon her by her husband. (763)

This also allowed a woman safety against her husband's financial status, as she would then be considered financially independent and no longer tied to the consequences of her divorced husband's fiscal decisions. The later statute detailed that the woman would obtain the same freedoms in a case of abuse from her husband. As women were considered men's property, these statutes were quite

\footnotetext{
${ }^{1}$ The punctuation acts as a monetary value, which would be equal to two pounds in 2017 .
} 
progressive in affording women autonomy. Rumpelstiltskin embodies a woman's fear of being unable to retain her rightfully-owned possessions. He does this by striking up deals in exchange for the miller's daughter's jewelry and even her baby. The daughter must comply because her life is under threat by another man, the king. This situation reflects how, during this time, a woman could not be wholly autonomous and perhaps feared losing what little autonomy she already possessed.

\section{HISTORY OF WOMEN IN THE SPINNING INDUSTRY}

At the time of the Industrial Revolution, literature evolved alongside various forms of industry. One way in which this can be studied is through analyzing the shifts in culture by recognizing shifts in literature. The story of "Rumpelstiltskin" is a perfect example of literary transformation because the story evolved to show how the practice of spinning underwent a transformation not only in industry but also in culture, due to industrialization. Though "Rumpelstiltskin" has been analyzed by various scholars, few have analyzed it with the intent of viewing the story in a sociocultural lens. However, scholar Jack Zipes analyzes "Rumpelstiltskin" in relation to the history of spinning and argues that this story told of the underlying shift from female productivity to the industrial male takeover of the spinning industry. By viewing this story through that lens, readers learn about how the male characters in "Rumpelstiltskin" resemble the monstrous way men took over the primarily female-run spinning industry during the Industrial Revolution.

Gerbug Treush-Dieter, professor of sociology at the Free University of Berlin, relays important background information on the history of spinning when she says, "It is a historical fact that the spindle remained in the hands of women until the invention of the spinning machine. Spinning can be considered as the paradigm of female productivity" (qtd. in Zipes 50). Although the spinning industry was run by women and was the foundation for female productivity, the spinning industry became a double-edged sword for women. On one edge of the sword, women could take their own agency when they worked through spinning. On the other edge, spinning enabled men to participate in monstrous conduct as the spinning industry "enabled men to profit from the surplus production of women that lead to primitive accumulation and also enabled men to deny their dependence on women's productivity by moving it out of their sight" (Zipes 52). The industry of spinning became even more of a tool against women when James Hargreaves' spinning machine was created in 1764 . With the rise of this invention, the spinning industry began to be taken over by men. Life was not better for those women who were able to work as "in those cases where women remained on the job, the management was predominantly in the hands of men" (Zipes 54- 
55). Over time, as the spinning industry gradually was given over into the hands of men, ramifications showed up in various ways throughout society for women who worked as spinners. One way in which this happened was through the way men changed the definition of spinners, originally known as women who spun, to spinsters, now synonymous with the stereotypes of old maids ("Spinsters and Spinners").

Therefore, readers can see that the character of Rumpelstiltskin functions as a monster throughout the story as he is a symbol of the men who took over the primarily female-run industry of spinning at this particular time in history. Rumpelstiltskin is a male character who ends up doing the miller's daughter's job, similar to how men ended up taking over the spinning industry and taking away female agency, for the monster is "an embodiment of a certain cultural moment" and its body "incorporates fear ... [and] anxiety" (Cohen 4). By viewing Rumpelstiltskin through this monster theory lens, readers are able to make connections across the text and history, realizing that Rumpelstiltskin embodies the cultural moment of the Industrial Revolution. The way he is portrayed by storytellers also reflects the anxiety and fear that female spinners experienced during this time. Therefore, the character of Rumpelstiltskin reflects female spinners' anxiety and fears regarding the male takeover of the spinning industry in the Industrial Revolution.

\section{ADAPTATIONS OF "RUMPELSTILTSKIN" RELATING TO WOMEN'S ROLES-DIANE STANLEY'S RUMPELSTILTSKIN'S DAUGHTER AND THE TELEVISION SERIES ONCE UPON A TIME}

Although "Rumpelstiltskin" is a well-known and old story, it contains motifs that have evolved over time and are still represented within modern culture, the main motif being that men are superior to women in society and wherever power is paramount. One instance of "Rumpelstiltskin" being retold in the modern era is Diane Stanley's children's picture book Rumpelstiltskin's Daughter. Stanley's children's story is heralded as a feminist retelling, utilized to teach and to inspire her audience. Within the story, the gold-spinning maid does not marry the king, for he is of unreputable character. Instead, she marries Rumpelstiltskin, who is portrayed as a reliable, attractive guy - a departure from the original tale that makes it more relatable to a modern audience, who would want to see her choose her husband. The maid and Rumpelstiltskin conceive a daughter who stumbles into her mother's footsteps. The young girl is captured by a greedy king and is commanded to spin straw into gold. However, the young damsel outwits the king and utilizes the gold to aid poor families, proving that abysmal situations can become beneficial. Afterwards, the maiden convinces the king to share his wealth 
with the farmers who then grow golden crops (Stanley). But, despite the fact that Rumpelstiltskin metamorphosed into the proverbial knight in shining armor, he still controls the maiden through his rescuing of her, which is similar to the original Rumpelstiltskin, who forced the maiden into a deal where she had little autonomy. Albeit, the daughter frees herself from capture and peril through manipulation, much as her father would. Despite maintaining some of the characterization from the traditional tale, the children's book teaches young girls to take back the power that men wield over them. The daughter is empowered through her cleverness and does not allow men to rule over her. This, however, is only one modern version of "Rumpelstiltskin," and not all such stories portray Rumpelstiltskin as the hero.

In the television series Once Upon a Time, Rumpelstiltskin is the beast to Belle's beauty. However, when he is transformed into a being known as the Dark One, despite his love for Belle, he perpetually abuses her - mainly emotionally, but at times physically as well. The relationship between Rumplestiltskin and Belle further illustrates that Rumpelstiltskin is a representation of men having control over women. However, as Rumplestiltskin chose to reject his role as the Dark One and become a hero for Belle's safety, there was a belief among the other characters that Rumpelstiltskin could represent transformation and hope. This was disproved when he chose to become the Dark One again, as, ultimately, for him, power is paramount to everything else. Much like the characterization of Rumpelstiltskin from the Brothers Grimm tale, this Rumpelstiltskin is focused on maintaining control over others through deception and trickery for his own gain. Although the two modern adaptations illustrate different messages, both adaptations are utilized to address gender issues: Stanley's book in order to educate a younger audience about self-empowerment regardless of gender, and Once Upon A Time in order to discuss issues of power and abuse within patriarchal society.

\section{"Rumpelstiltskin" by Brothers Grimm²}

By the side of a wood, in a country a long way off, ran a fine stream of water; and upon the stream there stood a mill. The miller's house was close by, and the miller, you must know, had a very beautiful daughter. She was, moreover, very shrewd and clever; and the miller was so proud of her, that he one day told the king

\footnotetext{
2 The Brothers Grimm version of "Rumpelstiltskin" is an example of a story that was most likely told by female spinners during the seventeenth and eighteenth centuries, which served simultaneously as a form of entertainment and a warning for female spinners (Zipes 43).

${ }^{3}$ The king's action reflects the commodification of women before the Married Property Act was passed.

This means that, after marriage, all of the spun gold would become the king's.
} 
of the land, who used to come and hunt in the wood, that his daughter could spin gold out of straw. Now this king was very fond of money; and when he heard the miller's boast his greediness was raised, and he sent for the girl to be brought before him. ${ }^{3}$ Then he led her to a chamber in his palace where there was a great heap of straw, and gave her a spinning-wheel, and said, 'All this must be spun into gold before morning, as you love your life. ${ }^{34}$ It was in vain that the poor maiden said that it was only a silly boast of her father, for that she could do no such thing as spin straw into gold: the chamber door was locked, and she was left alone.

She sat down in one corner of the room, and began to bewail her hard fate; when on a sudden the door opened, and a droll-looking little man hobbled in, and said, 'Good morrow to you, my good lass; what are you weeping for?' 'Alas!' said she, 'I must spin this straw into gold, and I know not how.' 'What will you give me,' said the hobgoblin ${ }^{5}$, 'to do it for you?' 'My necklace,' replied the maiden. He took her at her word, and sat himself down to the wheel, and whistled and sang:

'Round about, round about,

Lo and behold!

Reel away, reel away,

Straw into gold!'

And round about the wheel went merrily; the work was quickly done, and the straw was all spun into gold.

When the king came and saw this, he was greatly astonished and pleased; but his heart grew still more greedy of gain, and he shut up the poor miller's daughter again with a fresh task. Then she knew not what to do, and sat down once more to weep; but the dwarf soon opened the door, and said, "What will you give me to do your task?'” 'The ring on my finger,' said she. So her little friend took the ring, and began to work at the wheel again, and whistled and sang:

'Round about, round about,

Lo and behold!

Reel away, reel away,

Straw into gold!'

till, long before morning, all was done again.

The king was greatly delighted to see all this glittering treasure; but still he

\footnotetext{
${ }^{4}$ When realizing that the spinning industry was being taken over by males when this story was created, readers can see that the King character represents a male-run industry that employed women but that was managed by males and their greed.

${ }^{5} \mathrm{~A}$ hobgoblin is a "mischievous imp or sprite" and a "fearsome mythological creature" ("Hobgoblin").

${ }^{6}$ Almost all of the versions of "Rumpelstiltskin" portray him as making deals that he thinks will benefit him. These characteristics are taken from the Brothers Grimm "Rumpelstiltskin."
} 
had not enough: so he took the miller's daughter to a yet larger heap, and said, 'All this must be spun tonight; and if it is, you shall be my queen.' As soon as she was alone that dwarf came in, and said, 'What will you give me to spin gold for you this third time?' 'I have nothing left,' said she. 'Then say you will give me,' said the little man, 'the first little child that you may have when you are queen.' That may never be, 'thought the miller's daughter: and as she knew no other way to get her task done, she said she would do what he asked. Round went the wheel again to the old song, and the manikin once more spun the heap into gold. The king came in the morning, and, finding all he wanted, was forced to keep his word; so he married the miller's daughter, and she really became queen.

At the birth of her first little child she was very glad, and forgot the dwarf, and what she had said. But one day he came into her room, where she was sitting playing with her baby, and put her in mind of it. Then she grieved sorely at her misfortune, and said she would give him all the wealth of the kingdom if he would let her off, but in vain; till at last her tears softened him, and he said, 'I will give you three days' grace, and if during that time you tell me my name, you shall keep your child.'

Now the queen lay awake all night, thinking of all the odd names that she had ever heard; and she sent messengers all over the land to find out new ones. The next day the little man came, and she began with TIMOTHY, ICHABOD, BENJAMIN, JEREMIAH, and all the names she could remember; but to all and each of them he said, 'Madam, that is not my name.'

The second day she began with all the comical names she could hear of, BANDY-LEGS, HUNCHBACK, CROOK-SHANKS, and so on; but the little gentleman still said to every one of them, 'Madam, that is not my name.'

The third day one of the messengers came back, and said, 'I have travelled two days without hearing of any other names; but yesterday, as I was climbing a high hill, among the trees of the forest where the fox and the hare bid each other good night, I saw a little hut; and before the hut burnt a fire; and round about the fire a funny little dwarf was dancing upon one leg, and singing:

"Merrily the feast I'll make.

Today I'll brew, tomorrow bake;

Merrily I'll dance and sing,

For next day will a stranger bring.

Little does my lady dream Rumpelstiltskin is my name!"

When the queen heard this she jumped for joy, and as soon as her little friend came she sat down upon her throne, and called all her court round to 
enjoy the fun; and the nurse stood by her side with the baby in her arms, as if it was quite ready to be given up. Then the little man began to chuckle at the thought of having the poor child, to take home with him to his hut in the woods; and he cried out, 'Now, lady, what is my name?' 'Is it JOHN?' asked she. 'No, madam!' Is it TOM?' 'No, madam!' 'Is it JEMMY?' 'It is not.' 'Can your name be RUMPELSTILTSKIN?' said the lady slyly. 'Some witch told you that!- - some witch told you that!' cried the little man, and dashed his right foot in a rage so deep into the floor, that he was forced to lay hold of it with both hands to pull it out.

Then he made the best of his way off, while the nurse laughed and the baby crowed; and all the court jeered at him for having had so much trouble for nothing, and said, 'We wish you a very good morning, and a merry feast, $\mathrm{Mr}$ RUMPLESTILTSKIN!'

\section{EXCERPT FROM "A VINDICATION OF THE RIGHTS OF WOMAN"}

Published in 1792, Mary Wollstonecraft's "A Vindication of the Rights of Woman" argues that, in order to be a man's equal, a "woman must be educated in order to spread knowledge, virtue, and truth" (210). Wollstonecraft's work is, arguably, some of the first feminist writing in England. As such, Wollstonecraft's beliefs regarding the education of women are reflected in the following statement:

Women are told from their infancy, and taught by the example of their mothers, that a little knowledge of human weakness, justly termed cunning, softness of temper, outward obedience, and a scrupulous attention to a puerile kind of propriety, will obtain for them the protection of a man; and should they be beautiful, every thing else is needless, for, at least, twenty years of their lives. (295)

This indication of the ideology of women's behavior is well represented within "Rumpelstiltskin," as the miller's daughter seeks only to obtain the protection of a husband through obedience, thus spinning gold. However, the maid displays only outward obedience towards Rumpelstiltskin as she cunningly discovers his name, allowing her to save her firstborn child. The maid is defying gender norms, as she tricks Rumpelstiltskin with her cunning and intellect, and thus does not wholly obey his word. However, the miller's daughter still abides by the rules of Rumpelstiltskin's deal and still marries the man who manipulated her into creating wealth for his use; thus she is still conforming to society's ideals. Wollstonecraft argues against this type of behavior. While "Rumpelstiltskin" is an example of how monstrous gender norms can be, "A Vindication of the Rights of Woman" sought to free women from those constricting bonds by spreading education of feminist ideals. 


\section{EXCERPT FROM: "THE WEAVER AND THE FACTORY MAID"}

Before the Brothers Grimm published "Rumpelstiltskin" in 1812, various versions of the story were told orally. Songs were another traditional method of oral storytelling. "The Weaver and the Factory Maid" is a broadside by Preston Harkness. A broadside is "a descriptive or narrative verse or song, commonly in a simple ballad form, on a popular theme, and sung or recited in public places or printed on broadsides for sale in the streets" ("Broadside Ballad"). These broadsides were paid for and passed on orally, similar to the process by which "Rumpelstiltskin" was told and evolved.

Although the lyrics in the broadside below refer to weaving as opposed to spinning seen in "Rumpelstiltskin," both art forms can be analyzed as industries that historically employed women until the Industrial Revolution. Since the Industrial Revolution influenced the creation of machine looms at the end of the eighteenth century, many female weavers and spinners were put out of business and replaced by machine loom operators, who were either male or female (Gullickson 195). However, females who operated machine looms were seen as monstrous for not fitting into society's gender roles of domesticity at that time. Furthermore, skilled workers were being replaced by unskilled machine workers for lower pay, while rich men still controlled the factories. Along with this, since textile work was leaving the domestic sphere in general, women who wanted to engage in those careers now had to work solely for men.

In "The Weaver and the Factory Maid" by Preston Harkness, readers also see how the narrator is treated based on cultural expectations when he reveals his love of a factory maid while he still has a rare job as a hand weaver:

I am a hand weaver to my trade,

I fell in love with a factory maid;

And if I could but her favour win,

I'd stand beside her and weave by steam.

My father to me scornful said,

'How could you fancy a factory maid,

When you could have girls fine and gay,

And dressed like to the Queen of May?'

'As for your fine girls, I do not care;

And could I but enjoy my dear,

I'd stand in the factory all the day,

And she and I'd keep our shuttles in play.' (1-12) 
When the narrator admits he is a hand weaver, readers learn that he is a skilled weaver. He states that "he fell in love with a factory maid," which is another name for a girl who operates a steam loom in a factory. To say that he "would stand beside her and weave by steam" at the same factory is an abomination to the weaver's family and other hand weavers, as skilled hand weavers were being replaced by machinery, i.e. steam looms, operated mainly by male workers and other cheap labor. The father in these lyrics represents the revolting working class as those in the working class and other hand weavers would likely ask:

'How could you fancy a factory maid, When you could have girls fine and gay, And dressed like to the Queen of May?' (Harkness 6-8)

These lyrics also reveal how the working class viewed the women who worked at steam loom factories as monstrous. As men were traditionally the prime operators of machinery, women were monsterized for not being domestic and submissive. Along with this, the skilled male hand weaver in the poem above has been displaced by the cheap labor of the female steam weaver and his father does not approve of him joining her in the factory to work side by side. Although not a direct parallel, readers can see how the character of Rumpelstiltskin relates to the struggles of the working class in this poem as Rumpelstiltskin is a skilled hand weaver who has been displaced by the cheap labor of the maiden. Subsequently, readers learn that, although the working class see these factory maids as monstrous, the true monstrosity lies with those like the father who represent the working class as he does not consent for his son, nor his son's lover, to cross the boundaries of social propriety.

\section{EXCERPT FROM: "TOM TIT TOT"}

Published in 1898, “Tom Tit Tot,” an English variant of the Brothers Grimm "Rumpelstiltskin," showcases foundational aspects of the plot and culture that both stories, and other versions of "Rumpelstiltskin," are built upon. For example, in both "Tom Tit Tot" and "Rumpelstiltskin," there are male characters who take advantage of female spinners. One of these characters is the king figure. In "Rumpelstiltskin," the king's greed compels the king to have the maiden spin straw into gold not once, but three times, with a larger amount of straw being spun each time. As a reward, he tells the maiden that, if she can spin all of the straw in an even larger heap into gold, he will marry her, and she will become queen. Here, readers see the similarities between the king in "Rumpelstiltskin" mentioned above and the king in 
"Tom Tit Tot" below:

Then he said: "Look you here, I want a wife, and I'll marry your darter. But look you here,' says he, "leven months out o'the year she shall have all the vittles she likes to eat, and all the gownds she likes to git, and all the cumpny she likes to hev; but the last month o' the year she'll ha' to spin five skeins iv'ry day, an' if she doon't, I shall kill her.' (Clodd 11)

In both versions of the story, the king offers to marry the maiden if she will spin for him. It is important to note that, even though each version has different requirements ordered by the king figure, the concept and symbolism behind each king's desire is the same. Both king characters imply that, during this time, spinning was an industry that employed women but was managed by males and their greed. Therefore, this greed makes the king characters seem monstrous to readers in both stories, as the king in "Rumpelstiltskin" tells her to spin all the gold before morning "as you love your life," (The Brothers Grimm) and the king in "Tom Tit Tot" will kill the maiden if she does not reach the quota of five skeins, or lengths of gold thread, every day for a month (Clodd 11).

Another concept in both "Rumpelstiltskin" and "Tom Tit Tot" is that a male creature helps the maiden spin. Along with this, in both stories, the maiden has to figure out the creature's name so that she will not lose vital aspects of her life. In "Rumpelstiltskin" the creature is defined as a hobgoblin who gives the maiden three chances to figure out his name. Below, readers see how the creature who helps the maiden is portrayed in "Tom Tit Tot":

Well, she were that frightened. She'd allus been such a gatless mawther, the she didn't se much as know how to spin, an' what were she to dew tomorrer, with no one to come nigh her to help her. She sat down on a stool in the kitchen, and lork! How she did cry!

Howsivir, all on a sudden she hard a sort of a knockin' low down on the door. She upped and oped it, an' what should she see but a small little black thing with a long tail. That looked up at her right kewrious, an' that she said-

'What are yew a crin' for?'

'Wha's that to yew?' says she.

'Niver yew mind,' that said, 'but tell me what you're a cryin' for.'

'That oon't dew me noo good if I dew,' says she.

'Yew doon't know that,' that said an' twirled that's tail round.

'Well,' says she, 'that oon't dew no harm, if that doon't dew no good,' and she upped and told about the pies an' the skeins an' 
everything.

'This is what I'll dew,' says the little black thing: 'I'll come to yar winder iv'ry mornin' an' take the flax an' bring it spun at night.'

'What's your pay?' says she.

That looked out o' the corners o' that's eyes an' that said: 'T'll give you three guesses every night to guess my name, an' if you hain't guessed it afore the month's up, yew shall be mine.' (Clodd 11-12) Just as readers saw how the king characters in both stories were different in how they satisfied their greed but similar in their symbolic meaning, the creatures' physical attributes in both stories are different, though both have the same symbolism. The symbolism of the creatures is defined below:

As the old legends show, and as is also manifest in the 'Tom Tit Tot' group of stories, he [the creature who assists the maiden in spinning] is the transformed giant or wizard with the superadded features of the fiend whose aim it is to induce the unwary to agree to sell themselves to him at the price of some fleeting advantage. (Clodd 48)

In this case, although the creature in "Tom Tit Tot" is described as "a black thing" and the creature in "Rumpelstiltskin" is described as a "hobgoblin," both characters symbolize those who take advantage of and manipulate others; as the creatures' aims are to "induce the unwary to agree to sell themselves to him at the price of some fleeting advantage" (Clodd 48). When keeping in mind the historical lenses through which the reader can analyze these stories, readers see that these creatures symbolize men who took over the spinning industry, as the maiden has to rely on the male creatures' seemingly magical power of spinning when she can either not spin enough or her spinning is not of a high enough quality.

\section{EXCERPTS FROM: "THE PHILOSOPHY OF RUMPELSTILT-SKIN"}

A.W.T. and Edward Clodd's "Philosophy" consists of detailed summaries of each of the fourteen versions of "Rumpelstiltskin," which were told in various regions of Europe and other places. This piece was originally read before the Folklore Society on February $26^{\text {th }}, 1889$. Looking at different versions of the same story is helpful in identifying common themes which present themselves across the variants. Those themes, which are common to variants of "Rumpelstiltskin," are about the events of marriage as well as the discovery of the name of the stranger who helps the female protagonist. The general plotline remains the same as well, with a favor offered on the terms of a specified condition, which is foiled only if the woman can discover the name of the helper.

After the summary of each story and their respective plotlines, A.W.T. and 
Clodd provide three points from which to view the stories and to explain what is to be gained from their comparison. The first point explains the sacred nature of names in most world religions, including the Abrahamic religions: Christianity, Islam, and Judaism. This first point also mentions a similar phenomenon which is apparent in the beliefs of indigenous peoples, who are, in this piece, referred to as "savages," an outdated term more commonly used during the time it was written. It reads:

If we incline to accept the testimony of spiritualists we may find like correspondences between barbarian and civilized in the belief that to name the spirits is to invoke their appearance, an idea surviving in the saying, "Talk of the devil and you'll see his horns," and illustrated by the legend of the Norse witches who tied up wind and foul matter in a bag, and then, undoing the knots, shouted "Wind in the devil's name," when the hurricane is swept over land or sea....We may not therefore feign surprise when we hear that in Borneo, when a child is ill, its name is changed so as to confuse or deceive the bad spirits, to whom all diseases and death, which last is rarely regarded as a natural event by the savage, are ascribed. Among some South American tribes, when a man dies, his friends and kinsmen change their names so as to elude death if he comes after them, or to prevent the departed spirits being attracted back to earth by hearing the old name. (A.W.T. and Clodd 156)

This pattern is relevant to the Brother Grimm's "Rumpelstiltskin" because of the power that Rumpelstiltskin's name had to free the protagonist from having to give up her first born child. The inspiration for the manner in which the woman is freed must have come from one of the folk beliefs which associate names with power. Though where the inspiration originated cannot be confirmed, A.W.T. and Clodd provide relevant examples from around the world. The second point illustrated by "The Philosophy of Rumpelstilt-Skin" explains how the reluctance to utter names elevates with the status of the particular person in question. Many examples are provided from various cultures at the time. It reads:

we find that the Australian has a strong reluctance to tell his real name to strangers. So has the Kaffir, and among this race no woman may pronounce the names of any of her husband's male relations in the ascending line, nor even any word in which the principal syllable of the name of her father-in-law occurs. The Amazulu woman, when addressing or speaking of her husband, calls him "Father of So-andso," mentioning one of his children, and in like manner a Hindoo wife 
speaks of her husband as "He," "Swamy," or "the Master," avoiding the mention of his name. Dorman says that the New Mexican tribes never made known their own names or those of friends to a stranger, lest these should be used in sorcery. Among the Ojibways husbands and wives never told each others' names, and the children were warned that if they repeated their own names they would stop growing. (A.W.T. and Clodd 159)

These various examples illustrate how important and mystical names were in the folklore of the time, and they also show how names were believed to be innately tied to the human to which they were ascribed. The third and final point serves as a conclusion to the article and comments on the piece as a whole:

We have scampered across wide areas in our search after ideas common to those which lie at the heart of "Tom Tit Tot," and we find its variants, and the barbaric notions cognate to those ideas, contributing their evidence to that of the great cloud of witnesses testifying to the like attitude of the mind before like phenomena which frightened and bewildered it, until Science created sympathy between man and the objects of his undisciplined fears. (A.W.T. and Clodd 161) 


\section{WORKS CITED}

A. W.T., and Edward Clodd. "The Philosophy of Rumpelstilt-Skin.” The FolkLore Journal, vol. 7, no. 2, 1889, pp. 135-163. JSTOR, www.jstor.org/ stable/1252656. Accessed 20 Feb. 2017.

"Broadside Ballad." Encyclopedia Britannica, www.britannica.com/art/broadsideballad. Accessed 22 Feb. 2017.

The Brothers Grimm. "Rumpelstiltskin.” Grimms' Fairy Tales. Translated by Edgar Taylor and Marian Edwardes, The Project Gutenberg, https://www.gutenberg. org/files/2591/2591-h/2591-h.htm\#link2H 4 0027. Accessed 14 Dec. 2016.

Cohen, Jeffrey Jerome. "Monster Culture (Seven Theses).” Monster Theory: Reading Culture, edited by Jeffrey Jerome Cohen, University of Minnesota Press, 1996, pp. 3-25.

Clodd, Edward. "Tom Tit Tot: An Essay on Savage Philosophy in Folk-Tale." Duckworth, 1898, pp. 9-48.

Ellis, Sarah Stickney. "The Women of England: Their Social Duties and Domestic Habits." The Longman Anthology of British Literature, edited by David Damrosch and Kevin J. H. Dettmar, Pearson, 2012, pp. 1525-1527.

Gullickson, Gay L. Spinners and weavers of Auffay: rural industry and the sexual division of labor in a French village, 1750-1850. Cambridge, Cambridge University Press, 2002.

Harkness, Preston. "The Weaver and the Factory Maid." The Oxford Book of English Traditional Verse, edited by Fred Woods, Oxford University Press, 1983, pp. 303-304.

"Hobgoblin." Oxford Dictionaries, https://en.oxforddictionaries.com/definition/us/ hobgoblin, Accessed 22 Feb. 2017.

Hume, P. Leslie. Victorian Women: A Documentary Account of Women's Lives in Nineteenth Century England, France, and the United States. Edited by 
Hellerstein, Erna Olafson, et. al. Stanford University Press, 1981.

Lerner, Gerda. "Placing Women in History: Definitions and Challenges."

Feminist Studies, vol. 3, No. 1/2, 1975, pp 5-14. JSTOR,www.jstor.org/stable/ pdf/3518951.pdf?seq=1\#page scan tab contents. Accessed 17 Nov. 2016.

Stauffer, Derek. 'Once Upon a Time': Why Rumple Becoming the Dark One Again Is Infuriating.". buddyTV.com, 7 Dec. 2015, www.buddytv.com/articles/ once-upon-a-time/once-upon-a-time-why-rumple-bc-58260.aspx. Accessed 17 Nov. 2016.

Savage, Charles Chauncey. "Some Points of Comparison between English and American Legislation, as to Married Women's Property." The American Law Register (1852-1891), vol. 31, no. 12, 1883, pp. 761-768. JSTOR, www.jstor. org/stable/3304576. Accessed 6 Feb. 2017.

"Spinsters and Spinners." Knights of the Pain Table , Knights of the Pain Table, 30 May 2011, knightsofthepaintable.com/blog/2011/05/30/medieval-life-106spinsters-and-spinners/. Accessed 10 Nov. 2016.

Stanley, Diane. Rumpelstiltskin's Daughter. HarperCollins US, 1997, www. harpercollins.com/web-sampler/9780064410953. Accessed 01 Dec. 2016.

Wollstonecraft, Mary. "A Vindication of the Rights of Woman.” The Longman Anthology of British Literature, edited by David Damrosch and Kevin J. H. Dettmar, Pearson Education, 2010, pp. 288-310.

Zipes, Jack. "Spinning with Fate: Rumpelstiltskin and the Decline of Female Productivity." Western Folklore, vol. 52, no. 1, 1993, pp. 43-60. JSTOR, www. jstor.org/stable/1499492. Accessed 6 Feb. 2017. 